\title{
Producción de leche real vs la calculada a partir de la ENL estimada por el algoritmo de análisis de imágenes red-green-blue de gramíneas
}

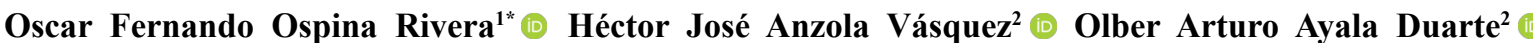

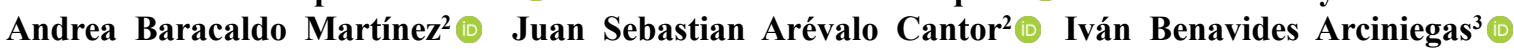 Daniel Eduardo Benavides Perez $^{3} @$ Gustavo Adolfo Galvis Enriquez ${ }^{3} \odot$}

\author{
${ }^{1}$ Servicios de Análisis de Explotaciones Pecuarias Ltda, SADEP Ltda, Bogotá, Colombia. \\ ${ }^{2}$ Fundación Universitaria Agraria de Colombia, Uniagraria, Bogotá, Colombia. \\ ${ }^{3}$ Cooperativa de Productos Lácteos de Nariño, Colácteos, Pasto, Nariño, Colombia. E-mail: oscar.ospina@tauruswebs.com. "Corresponding author.
}

ABSTRACT: Knowledge about the net lactation energy (NLE) contained in the dry matter of grasses is necessary to make decisions about forage and the balance of diets for grazing cattle. Its determination is made in laboratories using wet or dry chemistry methods, which are costly, delayed, and sometimes present sampling- or process-related reliability problems. An algorithm, which analyzes the red-green-blue (RGB) images of grasses taken by drone, has been developed as a technological alternative. This has allowed us estimating the NLE level, reducing costs, and changing the sampling system and analysis method. The objective of the present study was to compare the milk production, which was calculated from the NLE and estimated using the algorithm for analysis of RGB images of grasses (included in the TaurusWebs ${ }^{\mathbb{R}}$ software), vs the actual milk production. The study was conducted in 15 dairy farms belonging to the dairy control system of the Colácteos dairy cooperative, which are located in the upper tropical region (Department of Nariño, Colombia). The prairies evaluated were composed of mixtures of Kikuyo (Pennisetum clandestinum), Raigrás (Lolium spp), and False Poa (Holcus lanatus). The result was analyzed using a linear regression model $\left(R^{2}=0.86 ; R=0.93\right)$. In the Student's $t$-test, the actual and estimated milk production averages were equal $(P>0.05)$. In conclusion, the NLE calculated using the algorithm satisfactorily explains the study livestock production, and the information generated by the algorithm can be used to calculate the NLE of grasses.

Key words: algorithm, drone, bromatological analysis, $R G B$, net lactation energy.

Produção real de leite vs produção de leite calculada a partir da energía líquida de lactação estimada pelo algoritmo para análise de imagens vermelho-verde-azul de gramíneas

RESUMO: O conhecimento sobre a energia líquida de lactação (NLE) contida na matéria seca das gramíneas é necessário para a tomada de decisões sobre forragem e o equilibrio das dietas para pastagem. Sua determinação é feita em laboratórios usando métodos de química úmida ou seca, que são dispendiosos, atrasados e às vezes apresentam problemas de confiabilidade relacionados a amostras ou processos. Um algoritmo, que avalia as imagens vermelho-verde-azul (RGB) de gramíneas tiradas por drone, foi desenvolvido como uma alternativa tecnológica. Isso nos permitiu estimar o nível de NLE, reduzir custos e alterar o sistema de amostragem e o método de análise. O objetivo do presente estudo foi comparar a produção de leite, calculada a partir do NLE e estimada usando o algoritmo para análise de imagens RGB de gramineas (incluidas no software TaurusWebs ${ }^{\circledR}$ ) versus a produção real de leite. O estudo foi realizado em 15 fazendas leiteiras pertencentes ao sistema de controle de laticinios da cooperativa de laticinios Colácteos, localizada na região tropical superior (Departamento de Nariño, Colômbia). As pradarias avaliadas foram compostas por misturas de Kikuyo (Pennisetum clandestinum), Raigrás (Lolium spp) e False Poa (Holcus lanatus). O resultado foi analisado usando um modelo de regressão linear $\left(R^{2}=0,86 ; R=0,93\right)$. No teste t de Student, as médias reais e estimadas de produção de leite foram iguais $(P>0,05)$. Em conclusão, o NLE calculado usando o algoritmo explica satisfatoriamente a produção animal estudada, e as informações geradas pelo algoritmo podem ser usadas para calcular o NLE das gramineas.

Palavras-chave: algoritmo, drone, análise bromatológica, $R G B$, energia líquida de lactação.

\section{INTRODUCTION}

For dairy cow production systems, grazing is a low-cost food source, compared to balanced food or mixed raw materials. The problem of pasture-based dairies is that they have less net lactation energy (NLE) per kg of dry matter. In addition, they are susceptible to climatic effects, permanent change in the energy supply of the forage base, thus generating uncertainty in decision making (BARGO, MULLER, 
KOLVER, \& DELAHOY, 2003). After food enters the bovine organism, its energy content is dissipated in the form of gas, feces, urine, heat, etc. "At the end of this process, the energy for milk production, which is known as net lactation energy (NLE), remains" (WATTIAUX \& GRUMMER, 2000).

Van Soest proposed a wet chemistry technique, in which detergents are used at different hydrogen potential $(\mathrm{pH})$ values, reaching the Fiber in Neutral (NDF) and Acid (ADF) Detergent concepts. They have been used to calculate the energy from the digestibility of fibers and their interaction with protein fractions (BOSCHINI-FIGUEROA, 2006). The NLE can also be determined using a calorimetric pump, which allows quantifying the raw energy released by combustion of dry matter (RISSO, 2016). Dry chemistry methods based on the nearinfrared reflectance spectroscopy (NIRS), which are fast, widely diffused, and less polluting, have also been used successfully (COZZOLINO, FASSIO, \& GIMENEZ, 2001; VÁSQUEZ, ABADÍA, \& ARREAZA, 2004).

The red, green, and blue (RGB) format is an additive-synthesis-based color model, used in the RGB digital cameras. The primary colors can be stored in the *.jpg format, which is low-cost, reliable, and widely used in cell phones, computers, and drones (GERVAUTZ \& PURGATHOFER, 1988; IBRAHEEM, HASAN, KHAN, \& MISHRA, 2012). The *.jpg images can be processed using an algorithm that analyzes the color spectrum and identifies the wavelengths of light absorbed by the chloroplasts. With these wavelengths and a mathematical model, the amount of ENL of dry matter in the grasses can be estimated by this method, which will be called RGB image analysis algorithm.

In the upper tropical region of Nariño, Colombia, dairy herds predominantly use imported and naturalized grasses and legumes, which are eagerly consumed by dairy cows. Regarding supplementation to high production cows, they are supplied with balanced feed (MUÑOZ, 2015).

The objective of the present study was to compare the estimated ENL values using the algorithm for analysis of RGB images of the prairies. These values were converted to milk production potential and correlated with data of the actual production of cows at day 150 of the lactation curve in the dairy control system of Colacteos.

\section{MATERIALS AND METHODS}

The study was conducted in 15 farms belonging to the dairy cooperative Colacteos, located in the upper tropical region of Colombia at 3200 $\mathrm{m}$ altitude and average temperature $10{ }^{\circ} \mathrm{C}$. In the prairies of each dairy where the cows in production were grazing, images were taken at $100-\mathrm{m}$ high using a DJI Phantom III $^{\circledR}$ drone, with an RGB camera (12 megapixels) without filter, perpendicular to the ground.

The main grasses and legumes reported in the cattle farms were as follows: Kikuyo (Pennisetum clandestinum), Blue Orchoro (Dactylis glomerata), annual and perennial and dihybrid and tetrahybrid ryegrass (Lolium spp), Red Clover (Trifolium pratense), and White Clover (Trifolium repens). A sample $(500 \mathrm{~g})$ was collected from the supplements used in the livestock and sent to a private laboratory for chemical analysis and estimate of the NLE. Milk samples were collected from each livestock and sent to the milk quality laboratory of Colacteos for fat and protein analysis.

The images were processed for calculation of the NLE of the prairies using the algorithm for RGB image analysis (TAURUSWEBS ${ }^{\circledR}$ SOFTWARE; OSPINA, 2017) by a properly trained field professional.

The dairy production potential for grazing livestock was estimated with basis on the NLE data of the bromatological analysis of grasses, which was based on the RGB image analysis algorithm, and chemical analysis of supplements. For this estimate, we used the method reported by LAREDO, KLEEMANN, \& CUESTA (1985), which was compared with that proposed by ANRIQUE, MOLINA, \& ALFARO (2014), and the following model:

$\mathrm{VIDM}=\left(0.025^{*}\right.$ Weight $)+\left(0.12{ }^{*}\right.$ Milk production $)$

$\mathrm{NLEt}=\mathrm{VIDM}^{*} \mathrm{NLE} / \mathrm{kg} \mathrm{DM}$

NLEp $=$ NLEt - NLEm - NLEmov

$\mathrm{PMP}=\mathrm{NLEp} / \mathrm{NLEreq}$

where

Weight: Average weight of adult cows in the herd

Milk production: Estimated genetic potential for production of milk from herd cows

VIDM: Voluntary Intake of Dry Matter

DM: Dry Matter

NLE / kg DM: Amount of NLE per kg DM of cow ration

NLEt: Total NLE is the total contribution of ration energy

NLEm: NLE of maintenance, varies according to the weight of the cow

NLEmov: NLE consumed according to the movement of the cow (additional 10\% for every $3 \mathrm{~km}$ ).

NLEp: NLE for production 
NLEreq: NLE required to synthesize a liter of milk in the cow's udder.

PMP: Potential milk production of cows per NLE

With this method, the amount of NLEt

in the diet was estimated from the ration prepared with chemical analyzes; the NLEm was subtracted according to the weight of the cow, the NLEmov was subtracted, leaving the NLEp, which was divided by NLEreq per liter of milk, according to its fat and protein content, then determining the PMP of the cow by NLE in the lactation curve at day 150 .

The data on body weight and milk production of the cows were taken with cut at the date when the image was taken with the RGB camera mounted on a drone. Similarly, a professional estimated the genetic potential of the dairy cattle.

From the data on the NLE of the prairies calculated by the algorithm and NLE of the supplements, plus the estimated body weight and genetic potential data, the analysis of the diet was carried out at each livestock, using the milk production estimation model described above.

For the actual milk production, the data of day 150 of the lactation curve was taken from each of the 15 cattle farms, in the information system of the dairy control of Colacteos.

The milk production was estimated using the algorithm for the NLE and compared with the actual production obtained in the 15 farms.

The data collected were tabulated aligning real vs calculated production for each livestock. For the statistical analysis, the Stata (STATACORP, 2009) software was used, descriptive statistics was applied, statistical assumptions were verified, linear regression was applied, and the determination and correlation coefficients were calculated. For hypothesis testing, the Student's $t$-test was used.

\section{RESULTS AND DISCUSSION}

The values for NLE of grasses (estimated by the algorithm) and supplements (determined by chemical analysis performed in a commercial laboratory) are shown in table 1 . The calculated and actual milk production in each of the fifteen livestock farms are shown in table 2. Linear regression analysis was applied to the data shown in table 2 to estimate the values for $\mathrm{R}^{2}$ and $\mathrm{R}$ (Figure 1).

During the analysis of the relationship between milk production (calculated with basis on the NLE of the algorithm) and the real milk production, the determination $\left(\mathrm{R}^{2}=0.86\right)$ and correlation $(\mathrm{R}=0.93)$ coefficients were obtained. These values indicated that the milk production calculated from the NLE of the algorithm is highly correlated with the real milk production by the livestock (at day 150 of the lactation curve)

In the hypothesis test (Student's $t$-test), no significant difference was reported between the means of milk production (estimated with the NLE calculated with the algorithm) and the actual milk production by the livestock (at day 150 of the lactation curve; $p>0.05$ ).

The NLE values estimated by the algorithm (4.4-5.5 Mj NLE/Kg DM) were similar to those (4.2-6.0 $\mathrm{Mj} \mathrm{NLE} / \mathrm{Kg} \mathrm{DM}$ ) found in the Alimentro database (CORPOICA, 2018) for grasses (Kikuyo, Raigras, Brazilian Grass, and False Poa) of Nariño, Colombia (Table 1).

Regarding the NLE levels reported in the grasses evaluated, MÉNDEZ \& MÉNDEZ (2013) applied the method of LAREDO ET AL. (1985) to a dairy (550-kg live-weight cows fed with Kikuyo Raigras and high supplementation) and reported a milk production potential of $23.01 / \mathrm{cow} /$ day. The values determined in the present study (algorithmbased potential production: $24.1 \mathrm{l} / \mathrm{cow} / \mathrm{day}$; real production: $23.8 \mathrm{l} / \mathrm{cow} /$ day; table 2 ; farm 01 ), which was developed in a farm with similar conditions, agree with those of the literature. Conversely, these productions agree with those of the study of MUNOZZ (2015), who reported cows producing $24.0 \mathrm{l} / \mathrm{cow} / \mathrm{day}$, in the Raigras-Kikuyo prairies of Guachucal (Nariño, Colombia), with supplementation of $2.17 \mathrm{Kg} / \mathrm{DM} /$ day of commercial balanced feed containing $14 \%$ crude protein. CASTRO (2008) reported a production of $19.6 \pm 2.4 \mathrm{l} / \mathrm{cow} /$ day in the prairies of high Andean tropical region (Mosquera, Cundinamarca, Colombia), with a forage base composed of Kikuyo (Pennisetum clandestinum) and Festuca (Festuca arundinacea), and productions similar to those shown in table 2. Finally, MORALES-SUAREZ (2013) reported a production of 17.2-22.9 1/cow/ day by cows in the Sabana de Bogotá, Colombia, with prairies composed of Kikuyo (Pennisetum clandestinum), Festuca (Festuca arundinacea), and Lotus (Lotus corniculatus). The dairy production estimates of the present study are consistent with these data (Table 2).

Traditionally, quantification of the energy present in forages has been based on wet chemistry methodologies, such as the chemical analysis of Weende. This analysis included the calculation of crude protein, ethereal extract, nitrogen-free extract, ash, and raw fiber as elements for calculation of the total digestible nutrients 
Table 1 - Values for net lactation energy (NLE) of grass estimated by algorithm and supplements determined by chemical analysis.

\begin{tabular}{|c|c|c|c|c|c|}
\hline \multirow{3}{*}{$\begin{array}{l}\text { Farms } \\
\text { Livestocks }\end{array}$} & \multicolumn{5}{|c|}{ 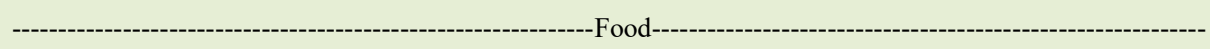 } \\
\hline & \multicolumn{2}{|c|}{------------------------Prairies-------------------- } & \multicolumn{3}{|c|}{------------------------------Supplements-------------------------------- } \\
\hline & $\mathrm{DM}(\%)$ & NLE (Mj) & $\mathrm{N}^{*}$ & $\mathrm{DM}(\%)$ & NLE $(\mathrm{Mj})$ \\
\hline \multirow{2}{*}{1} & \multirow{2}{*}{15} & \multirow{2}{*}{5.5} & 1 & 91 & 8.9 \\
\hline & & & 2 & 92 & 7.8 \\
\hline \multirow{2}{*}{2} & \multirow{2}{*}{18} & \multirow{2}{*}{4.6} & 3 & 93 & 7.1 \\
\hline & & & 4 & 94 & 6.9 \\
\hline \multirow{2}{*}{3} & \multirow{2}{*}{21} & \multirow{2}{*}{4.8} & 5 & 21 & 9.4 \\
\hline & & & 6 & 92 & 6.6 \\
\hline \multirow{2}{*}{4} & \multirow{2}{*}{25} & \multirow{2}{*}{4.7} & 5 & 21 & 9.4 \\
\hline & & & 7 & 93 & 8.7 \\
\hline \multirow{2}{*}{5} & \multirow{2}{*}{15} & \multirow{2}{*}{5.1} & 8 & 21 & 6.3 \\
\hline & & & 9 & 93 & 8.7 \\
\hline \multirow{2}{*}{6} & \multirow{2}{*}{15} & \multirow{2}{*}{4.9} & 10 & 24 & 4.8 \\
\hline & & & 11 & 92 & 7.8 \\
\hline \multirow{4}{*}{7} & \multirow{4}{*}{23} & \multirow{4}{*}{4.4} & 12 & 24 & 5.6 \\
\hline & & & 13 & 23 & 5.2 \\
\hline & & & 1 & 91 & 8.9 \\
\hline & & & 11 & 92 & 7.8 \\
\hline \multirow{4}{*}{8} & \multirow{4}{*}{16} & & 2 & 92 & 7.8 \\
\hline & & 51 & 14 & 88 & 7.9 \\
\hline & & 5.1 & 14 & 88 & 7.9 \\
\hline & & & $\mathrm{Fa}^{*}$ & 100 & 9.0 \\
\hline 9 & 19 & 4.8 & 11 & 92 & 7.8 \\
\hline 10 & 19 & 4.8 & 2 & 92 & 7.8 \\
\hline & & 5.0 & 1 & 91 & 8.9 \\
\hline 11 & 15 & & $\mathrm{Br}^{*}$ & 17 & 5.2 \\
\hline & & & 11 & 92 & 7.8 \\
\hline 12 & 18 & 4.8 & 13 & 23 & 5.2 \\
\hline 13 & 19 & 51 & 1 & 91 & 8.9 \\
\hline 13 & 19 & 5.1 & 2 & 19 & 5.1 \\
\hline & & & 11 & 92 & 7.8 \\
\hline 14 & 17 & 46 & 12 & 24 & 5.6 \\
\hline 14 & 17 & 4.0 & 14 & 88 & 7.9 \\
\hline & & & $\mathrm{Fa}^{*}$ & 100 & 9.0 \\
\hline & & & 3 & 93 & 7.1 \\
\hline 15 & 20 & 4.9 & 12 & 24 & 5.6 \\
\hline & & & 13 & 23 & 5.2 \\
\hline
\end{tabular}

* Br: Brazilian; DM: Dry matter; Fa: fat; N: Supplement number; NLE: net lactation energy.

(TDN). In the case of ruminants, this methodology presented problems due to the high fibrous content and low digestibility of grasses. Subsequently, wet chemistry advances were brought by Van Soest. He proposed the concepts of fibers in neutral (NDF) and acid (ADF) detergents, which have been used for calculation of energy of digestion of NDF and its interaction with protein fractions (BOSCHINIFIGUEROA, 2006). The NLE can also be determined by thermodynamic calculations using a calorimetric pump (RISSO, 2016). Subsequently, dry chemistry methods, which are based on nearinfrared spectroscopy (NIRS) (COZZOLINO ET AL., 2001; VÁSQUEZ ET AL., 2004), have been used successfully because they are less polluting, fast, and widely disseminated. In the present study, a new technology, other than wet chemistry, dry chemistry, and thermodynamic calculations, was evaluated for calculation of NLE. An algorithm for analysis of RGB images was used to process the light absorbed by grass chloroplasts, as a fast, reliable, and less expensive alternative.

Ciência Rural, v.51, n.2, 2021. 
Table 2 - Milk production calculated using the net lactation energy (NLE) of the algorithm and real milk production on day 150 of the lactation curve.

\begin{tabular}{|c|c|c|}
\hline Livestocks & Real productions (liters) & Calculated productions (liters) \\
\hline 01 & 23.8 & 24.1 \\
\hline 02 & 14.7 & 13.6 \\
\hline 03 & 14.2 & 14.7 \\
\hline 04 & 15.5 & 15.0 \\
\hline 05 & 20.7 & 21.0 \\
\hline 06 & 18.4 & 19.7 \\
\hline 07 & 18.8 & 19.3 \\
\hline 08 & 13.8 & 15.5 \\
\hline 09 & 15.2 & 15.8 \\
\hline 10 & 19.4 & 17.6 \\
\hline 11 & 22.7 & 20.3 \\
\hline 12 & 18.8 & 17.8 \\
\hline 13 & 15.9 & 15.4 \\
\hline 14 & 17.7 & 17.1 \\
\hline 15 & 20.6 & 19.0 \\
\hline Mean values & $18.0^{*}$ & 17.7 \\
\hline Standard deviations & 3.1 & 2.9 \\
\hline
\end{tabular}

${ }^{*} \mathrm{p}>0.05$.

\section{CONCLUSION}

A high correlation was reported between the actual milk production and that calculated with the algorithm for RGB image analysis $(\mathrm{R}=0.93)$, and no significant difference was found between their mean values $(\mathrm{P}>0.05)$.

It was verified that the algorithm of RGB image analysis could be used to quantify NLE in grasses of the prairies

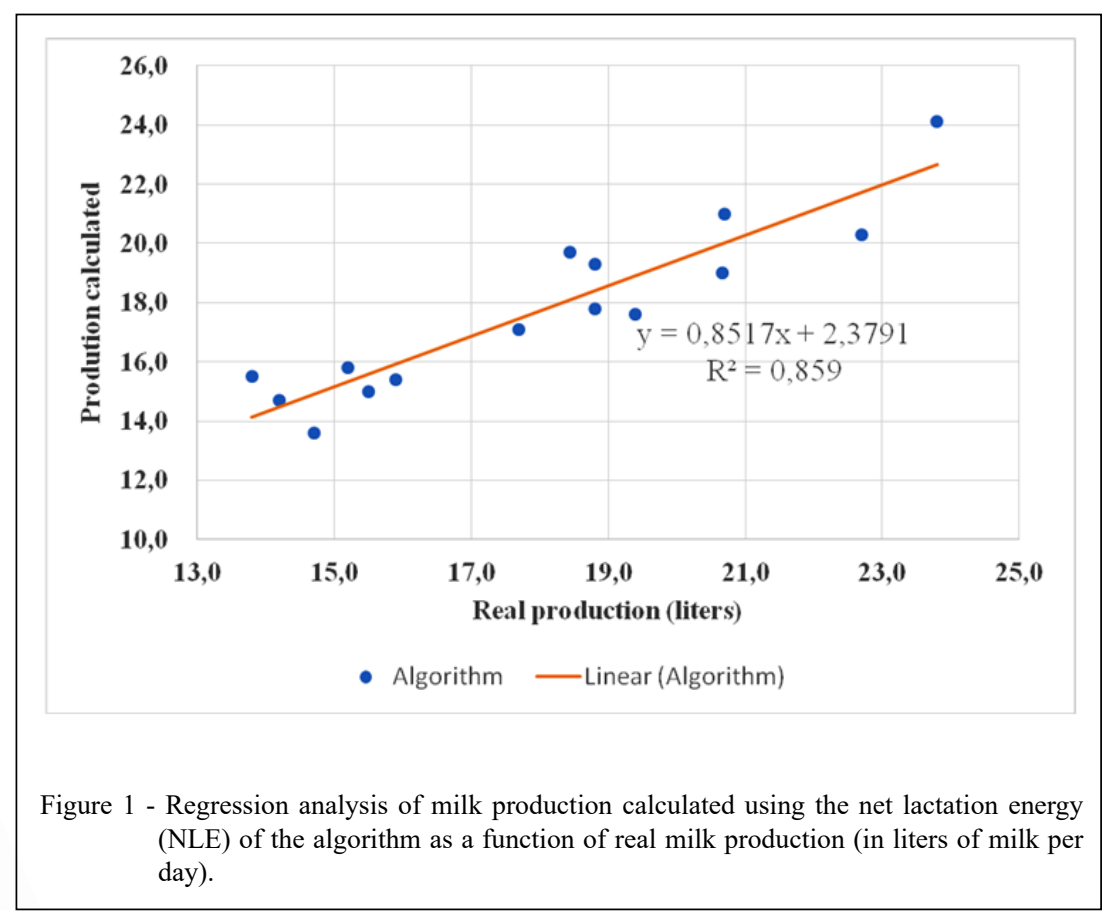

Ciência Rural, v.51, n.2, 2021. 


\section{DECLARATION OF CONFLICT OF INTERESTS}

The authors declare no conflict of interest. The founding sponsors had no role in the design of the study; in the collection, analyses, or interpretation of data; in the writing of the manuscript, and in the decision to publish the results.

\section{AUTHORS' CONTRIBUTIONS}

Oscar Fernando Ospina Rivera conceived and designed experiments. Daniel Eduardo Benavides Perez, Gustavo Adolfo Galvis Enriquez and Iván Benavides Arciniegas performed the experiments. Oscar Fernando Ospina Rivera and Daniel Eduardo Benavides Perez carried out the lab analyses. Oscar Fernando Ospina Rivera; Héctor José Anzola Vásquez; Olber Arturo Ayala Duarte and Andrea Baracaldo Martínez performed statistical analyses of experimental data. Oscar Fernando Ospina Rivera; Héctor José Anzola Vásquez; Olber Arturo Ayala Duarte; Andrea Baracaldo Martínez and Juan Sebastian Arévalo Cantor prepared the draft of the manuscript. All authors critically revised the manuscript and approved of the final version.

\section{REFERENCES}

ANRIQUe, G., MOLINA, X., \& ALFARO, A. Composición de alimentos para ganado bovino. Santiago de Chile: Consorcio Lechero, 2014. 4. ed., $100 \mathrm{pp}$. Available from: <http://www. consorciolechero.cl/chile/documentos/composicion-de-alimentospara-ganado-bovino.pdf>. Accessed: Aug. 1, 2019.

BARGO, F., MULLER, L., KOLVER, E., \& DELAHOY, J. Production and digestion of supplemented dairy cows on pasture. Journal of dairy science, v.86,(1), p.1-42, 2003. Available from: <https:// www.sciencedirect.com/science/article/pii/S0022030203735814>. Accessed: Aug. 15, 2019. doi: 10.3168/jds.s0022-0302(03)73581-4.

BOSCHINI-FIGUEROA, C. Nutrientes digeribles, energía neta y fracciones proteicas de la morera (Morusalba) aprovechables en vacas lecheras. Agronomía Mesoamericana, v.17,(2). p.141150, 2006. Available from: <https://revistas.ucr.ac.cr/index.php/ agromeso/article/view/5154>. Accessed: Aug, 15, 2019. doi: 10.15517/am.v17i2.5154.

CASTRO, R. M.; LEÓN, R.; PABÓN, M.;CARULlA, J.;CÁRDENAS, E. Productividad de pasturas y producción de leche bovina bajo pastoreo de gramínea y gramínea Lotus uliginosus en Mosquera, Cundinamarca. Revista Medicina Veterinaria Zootecnia. v.55, p.9-21. 2008. Available from: <https://revistas. unal.edu.co/index.php/remevez/article/view/10478>. Accessed: Aug. 25, 2019.

CORPOICA. Alimentro. 2018. Available from: <http://www. corpoica.org.co:8086/NetCorpoicaMVC/alimentro>. Accessed: Aug. 20, 2019.

COZZOLINO, D., FASSIO, A., \& GIMENEZ, A. The use of near-infrared reflectance spectroscopy (NIRS) to predict the composition of whole maize plants. Journal of the Science of Food and Agriculture. v.81(1). p.142146.2001. Available from: <https://onlinelibrary.wiley.com/ doi/abs/10.1002/1097-0010(20010101)81:1\%3C142::AIDJSFA790\%3E3.0.CO;2-I $>$. Accessed: Aug. 20, 2019. doi: 10.1002/1097.0010(20010101)81:1<142::AID-JSFA790>3.0.CO;2-I.
GERVAUTZ, M., \& PURGATHOFER, W. A simple method for color quantization: Octree quantization. In New trends in computer graphics. 1988. p.219-231. Available from: $<$ https:// link.springer.com/chapter/10.1007/978-3-642-83492-9_20>. Accessed: Aug. 10, 2019.

IBRAHEEM, N., HASAN, M., KHAN, R., \& MISHRA, P. Understanding color models: a review. ARPN Journal of Science and Technology. v.2(3), p.265-275. 2012. Available from: <http:// citeseerx.ist.psu.edu/viewdoc/download?doi=10.1.1.679.8051\&re $\mathrm{p}=$ rep1\&type $=$ pdf $>$. Accessed: Aug. 10, 2019.

LAREDO, M., KLEEMAnN, G., \& CUESTA, A. Tabla de contenido nutricional en pastos y forrajes de Colombia. Bogotá: Instituto Colombiano Agropecuario ICA. 1985. ISBN 9789589066232. Available from: <http://www.sidalc.net/cgi-bin/ wxis.exe $/$ ? IsisScript $=$ catalco.$x i s \&$ method $=$ post $\&$ formato $=2 \&$ cant idad=1\&expresion=mfn=029901>. Accessed: Aug. 10, 2019.

MORALES-SUAREZ, M. Valoración del rendimiento de gramíneas puras y asociadas con Lotus uliginosus y su influencia sobre la producción de leche y balance de nitrógeno de vacas Holstein en dos ecorregiones de la sabana de Bogotá y su área de influencia. 2013. Dissertation thesis M.Sc. Universidad Nacional de Colombia. Available from: <http://bdigital.unal.edu. co/39456/1/780217.2013.pdf>. Accessed: Aug. 15, 2019.

MUÑOZ, E. Planificación forrajera de fincas lecheras pertenecientes al círculo de excelencia de Fedegan, como herramienta para el mejoramiento de la competitividad ganadera del departamento de Nariño. 2015. Dissertation thesis. Universidad de Nariño. Available from: <http:// biblioteca.udenar.edu.co:8085/atenea/biblioteca/90970.pdf $>$. Accessed: Aug. 20, 2019.

MÉNDEZ, L., \& MÉNDEZ, C. Guía práctica de nutrición en pastoreo. Corcas Editores. Bogotá, Colombia. 2013. Accessed: Aug. 10, 2019.

OSPINA, O. TaurusWebs 2017. Sadep LTDA. Available from: $<$ http://www.tauruswebs.com/wwwtauruswebs/>. Accessed: Aug. 1,2019 .

RISSO, A. L. Conceptos Básicos de Nutrición en perros y gatos. Revista del Colegio de Veterinarios de la Provincia de Buenos Aires. 2016. v.20; 65; p.29-36. Available from: <https://ri.conicet. gov.ar/handle/11336/53482>. Accessed: Aug. 5, 2019.

STATACORP. Stata Version 11.2. College Station, Texas 77845 USA. 2009. Available from: <https://www.stata.com/>. Accessed: Aug. 1, 2019.

VÁSQUEZ, D. R., ABADÍA, B., \&ARREAZA, L. C. Aplicación de la Espectroscopía de Reflectancia en el Infrarrojo Cercano (NIRS) para la caracterización nutricional del pasto Guinea y del grano de maíz. Revista Corpoica: Ciencia y Tecnología Agropecuaria. v.5(1), p.49-55. 2004. Available from: <http://revista.corpoica.org. co/index.php/revista/article/view/24>. Accessed: Aug. 5, 2019. doi: 10.21930/rcta.vol5_num1_art:24.

WATTIAUX, M. A., \& GRUMMER, R. R. Lipid metabolism in dairy cows. Web site of Babcock Institute for International Dairy Research and Development. University of Wisconsin, USA. 2000. Available from: <https://federated.kb.wisc.edu/images/ group226/52745/4.LipidMetabolisminDairycows.pdf $>$. Accessed: Aug. 5, 2019. 